\title{
Econometric Modelling of the Fiscal Pressure on the Equilibrium of a Sample of Entities
}

\author{
Ioan Batrancea ${ }^{1}$
}

Babes-Bolyai University, Faculty of Economics and Business Administration, Teodor Mihali Str.58-60, Cluj-Napoca, Romania, telephone 0040744771329, fax: 0040264412570, email: ioan.batrancea@econ.ubbcluj.ro

Ioan-Dan Morar

Professor PhD, University of Oradea, Faculty of Economics, Armatei Romane Str.1-5, Oradea, Romania, telephone 0040744125977, fax: 0040259408209, email: morar_id@yahoo.com Liviu Bechis

Vasile Goldis University, Faculty of Economics, B-ul Revolutiei nr. 94, Arad, Romania, telephone 0040257280335, fax:0040257280810, email: liviubichis1960@yahoo.com

Sandor Csegedi

Ph.D., S.C.Transport Local S.A., Târgu Mureş, Romania,email: translocms@yahoo.com, telephone: 0040744808997, fax:0265268448

\section{Catalin Sabau}

PhD Student, Babes-Bolyai University, Faculty of Economics and Business Administration, Teodor Mihali Str.58-60, Cluj-Napoca, Romania, telephone 00749270569, fax: 0040264412570,email:cata_sab@yahoo.com

\footnotetext{
${ }^{1}$ For correspondence e-mail:ioan.batrancea@econ.ubbcluj.ro
} 


\begin{abstract}
The financial equilibrium of the enterprise is an important company function ensuring by itself the maintenance of the enterprise of the competitive market. The financial equilibrium is analysed in numerous empirical studies. In this empirical study we highlight for the first time in a research the impact that taxation has on the financial equilibrium of some companies over ten years, period that includes the pre-crisis, the financial crisis and postcrisis periods.
\end{abstract}

Keywords: fiscality, pressure, assets, debts, liquidity, solvency

\title{
Jel: C58, D03, D58, E62
}

\section{Introduction}

Taxes and fees have a dual quality in terms of financial equilibrium of companies or taxpayers. In this case, taxes and fees, on the one hand, represent an expense for businesses or taxpayers, and on the other hand, represent a duty or an obligation for them.

The development of the enterprise is unquestionably related to ensuring the economic equilibrium expressed in value. The financial equilibrium expresses equality and correlations between the necessary financial resources and the possibilities of collecting these resources. The financial equilibrium of the company requires covering all operating expenses from its own income or loan, all expenses that are not covered in costs, the costs of development and modernization of the enterprise, the expenses to stimulate staff and shareholders and the contractual obligations and the financial commitments to banks and the state budget.

The forms of financial equilibrium are expressed through the states of liquidity and solvency. While liquidity is a state of financial equilibrium expressing an entity's ability to pay on short term, by synchronizing during the financial year the cash inflows and outflows, solvency is the long-term ability of the enterprise. 
The status of liquidity is specific to the entity's operating cycle, that is, the time between the purchase of raw materials and the transformation of finished goods in cash or into an instrument readily convertible to cash. The solvency status is specific to the financial cycle comprising three overlapping cycles: the operational cycle, the investment cycle and the financing cycle.

Various works present either empirical research on taxation or on the enterprise's equilibrium, but so far there are no researches on the impact of taxation on the financial equilibrium of the company.

\section{Literature Review}

The financial crisis affected the performance and the fiscal pressure of each company which is mention in several works of art in analyzing both the banking crisis and the sovereign debt crisis. Public debt was considered one of the main reasons of concern for many countries. This problem became acute in the early $80 \mathrm{~s}$, when the early signs of the crisis occurred in several countries. This was manifested by the cessation of foreign debt payments. Such problems caused by public debt have come to the attention of both creditor states and those responsible for payment. In the early 1980s foreign debt crisis was manifested in several countries particularly indebted countries in Central and South America [1].

In recently published papers, there are analysed the correlations between the financial equilibrium and a series of independent factors that can ensure that state of enterprises.

Thus, in a recent paper Kuo et al. stress that in order to ensure the strategic equilibrium of companies, carbon emissions should be reduced by increasing the fees for the growth of these emissions. To achieve this goal, a series of countries have implemented tax policies to reduce carbon emissions by setting higher prices of carbon emissions, thus forcing polluting companies to invest in green technologies [2]. Other authors such as Wu et.al. built a general 
equilibrium model that takes into account the optimal short and long term privatization policies [3]. Another general equilibrium model is presented by Ji et.al. in which is analysed the tax reform in Chinese enterprises in the context of application of the $25 \%$ flat income tax. The research results showed that the optimal rate of taxation on a manufacturing company in China is $21.82 \%$ [4]. In another paper it is analysed the competition among supplier enterprises (cooperatives) and investor-owned firms (IOF) when acquiring different quality commodities from agricultural farmers [5]. Referring to the post-communist period, Lattore (2012) shows that entry of multinationals (MNE) in transition economies brings a process of restructuring of various industries. This process is illustrated by data on the rapid entry of multinational companies in the automotive sector in the Czech Republic, which took place before the financial crisis [6]. On the other hand, referring to the company's strategies, Granadier (2002) studies how the equilibrium investment strategies can be applied on a continuous basis, following the Cournot - Nash model [7]. Financial equilibrium depends by the cash flow which can be found in numerous papers. Thus, Găban (2016) shows that "in the financial reporting system, the balance sheet and profit and loss account are key elements throughout the world as part of periodical financial reporting while the cash flow statement is not mandatory in many countries (e.g. Germany and the Netherlands). In Japan, cash flow reporting is mandatory only for companies listed at the stock exchange market.”[8]

Analysing the behaviour of multinational companies, Latorre (2013) constructs a general equilibrium model to analyze the performance of companies. The model is applied to the Czech Republic where direct investment have been very attractive in the past three decades [9]. In another paper, Osborne et.al.(1986) focus on the study of symmetry of mixed strategy equilibrium for an arbitrary distribution of the number of consumers and firms[10]. Analysing the equilibrium at macroeconomic level, Coffinet and Pop (2013) show that the current financial crisis offers a unique opportunity to investigate the most important features of 
market indicators in a particular environment and their usefulness form a banking supervisory perspective. In general, both accounting information and stock exchange quotations contain useful information for achieving better forecasts in a highly stressed financial world [11].

Other authors present the method of quantitative assessment of brand equity. Using techniques of financial analysis focusing on return on equity and return on assets, the results of two strategies to increase equity are being analysed for distinct brands: increase in procurements and development of their own brand [12]. The equilibrium analysis based on financial ratios is presented in the paper showing that the analysis based on ratios in small and medium enterprises (SMEs) is very important. The paper analyzes the trends and dynamics of some of the most important financial ratios of the position and business ratio of the financial performance of SMEs in the Republic of Croatia [13]. The analysis of the equilibrium through the financial structure is presented by Townsed (2010) showing the need for an approach of the general equilibrium for assessing financial systems such as: the microeconomic sector and the macroeconomic sector, in order to reduce poverty and increase welfare [14].

\section{Research Methodology and Results}

In the research we have conducted we shall model the relationships existing between fiscal pressure indicators (Fiscal pressure rate to value added, fiscal pressure to equity, Fiscal pressure rate to turnover, Fiscal pressure rate to share capital, Fiscal pressure rate to resource consumption) and indicators reflecting the equilibrium of an enterprise (current liquidity ratio, overall solvency ratio, total borrowing rate, repayment capacity - CR and rate of selffinancing of tangible assets - RAIC). These demarches are taken in order to "pass" from a mere descriptive analysis of the situation that a company faces at a certain moment in time, to an in-depth analysis based on econometric analyses of the relationships established between 
the indicators brought under discussion. The data based on which this research was carried out come from a sample of five companies, selected randomly, whose evolution is tracked over a time period of ten years (2002-2011). Taking this into account, it is clear that we actually analysed a balanced panel. After a series of tests and subsequent removal of the various possible models at our disposal, we stopped on the general linear model derived from the Least Squares in Simple Form technique. This model was chosen to model the relationship between the variables because it fits quite well with available data, and it is also the only relevant model in terms of observance of considered creditworthy indicators (F statistics, adjusted $\mathrm{R}^{2}$ ).

The functional form of this model is as follows:

$$
y_{i t}=\alpha+X_{i t}^{\prime} * \beta+\varepsilon_{i t}, \quad i=\overline{1,5} ; t=\overline{1,10}
$$

where $\mathrm{y}_{\mathrm{it}}$-dependent variable

$$
\begin{aligned}
& \alpha \text { - constant } \\
& \mathrm{X}_{\mathrm{it}}^{\prime} \text { - independent variables } \\
& \beta \text { - regression coefficient } \\
& \varepsilon_{\text {it }} \text { - errors (independently and identically distributed) } \\
& \mathrm{i}-\mathrm{i} \text { company } \\
& \mathrm{t} \text { - year }
\end{aligned}
$$

In order to avoid overloading the results with text, we shall introduce notations for both dependent and independent variables, notations that will be used throughout the research. 
Fiscal pressure at the level of economic agents is determined using a system of indicators considered independent variables in our research and whose development we present below.

\section{Fiscal Pressure toTurnover - RPFca}

The indicator is calculated as a ratio of total social contributions and taxes and turnover.

Figure 1. The evolution of Fiscal pressure to turnover of a sample of entities

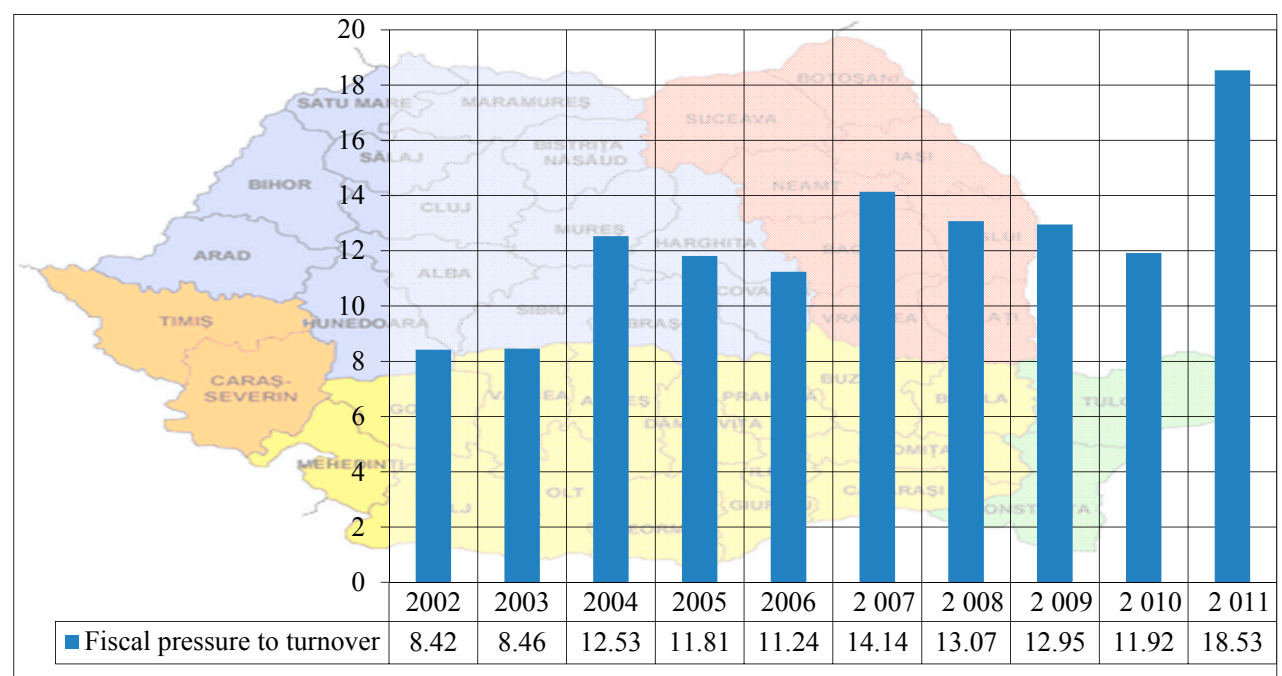

Source: Own calculus

The indicator highlights the capacity of repayment of fiscal and social obligations of the economic entity of current receipts. From the above data it is observed that the fiscal pressure increased over the period with acceleration during the financial crisis.

\section{Fiscal Pressure to Value Added - RPFva}

The indicator is calculated as a proportion between the total social contributions and taxes and the value added.

The indicator highlights the size of the own resources allocated to settle tax and social obligations of the economic agent. 
Figure 2. The evolution of fiscal pressure to value added

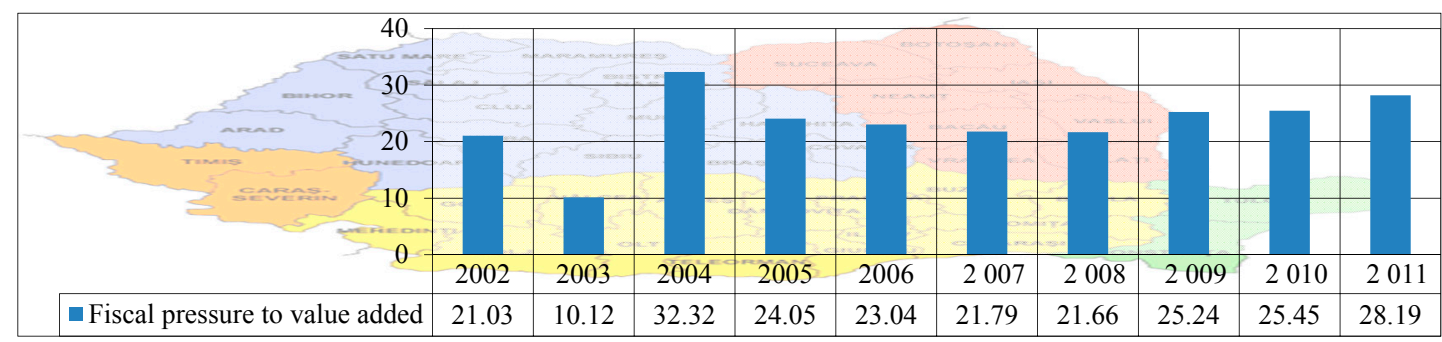

Source: Own Calculus

It results that about $25 \%$ of added value are directed to the state budget, the remaining $75 \%$

being available to businesses to pay for the factors of production, namely labour and capital.

\section{Fiscal Pressure to Equity - RPFcpr}

The indicator is calculated as a ratio of total taxes and fees and social contributions and equity.

The indicator highlights the company's equity capacity to cope with tax and social obligations incumbent upon a fixed period of time.

Figure 3. The evolution of Fiscal pressure to equity

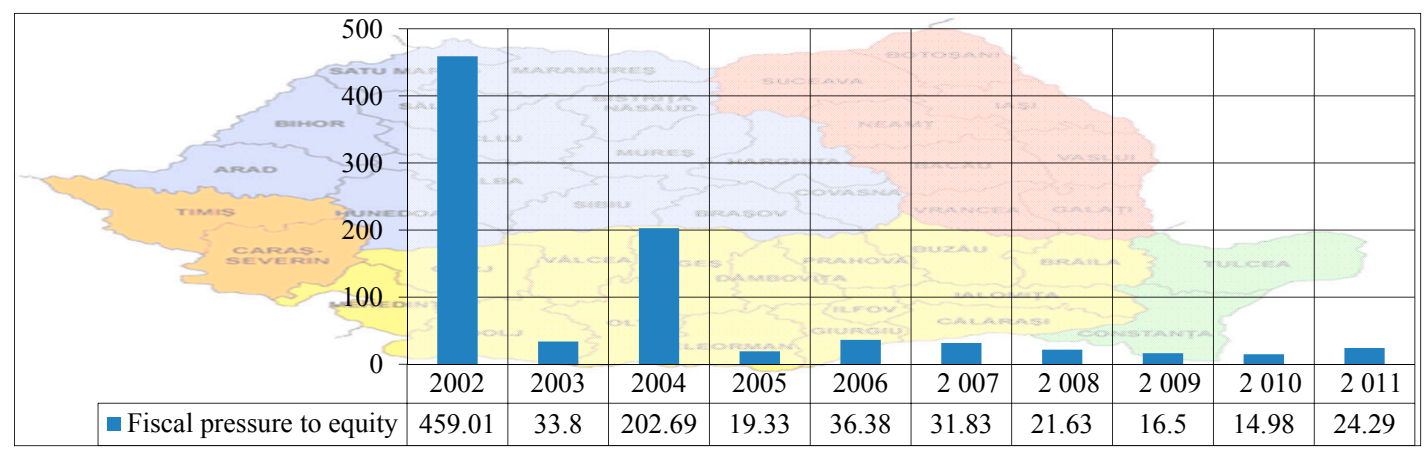

Source: Own calculus

Except for the years 2002 - 2004 when the fiscal pressure was unusually high, we note that after the financial crisis the level of taxation was at a level considered by many analysts, i.e. $14 \%-16 \%$. 
Fiscal Pressure to Share Capital - RPFes- is calculated as a ratio of total taxes and social contributions and share capital.

Figure 4. The evolution of fiscal pressure to social capital

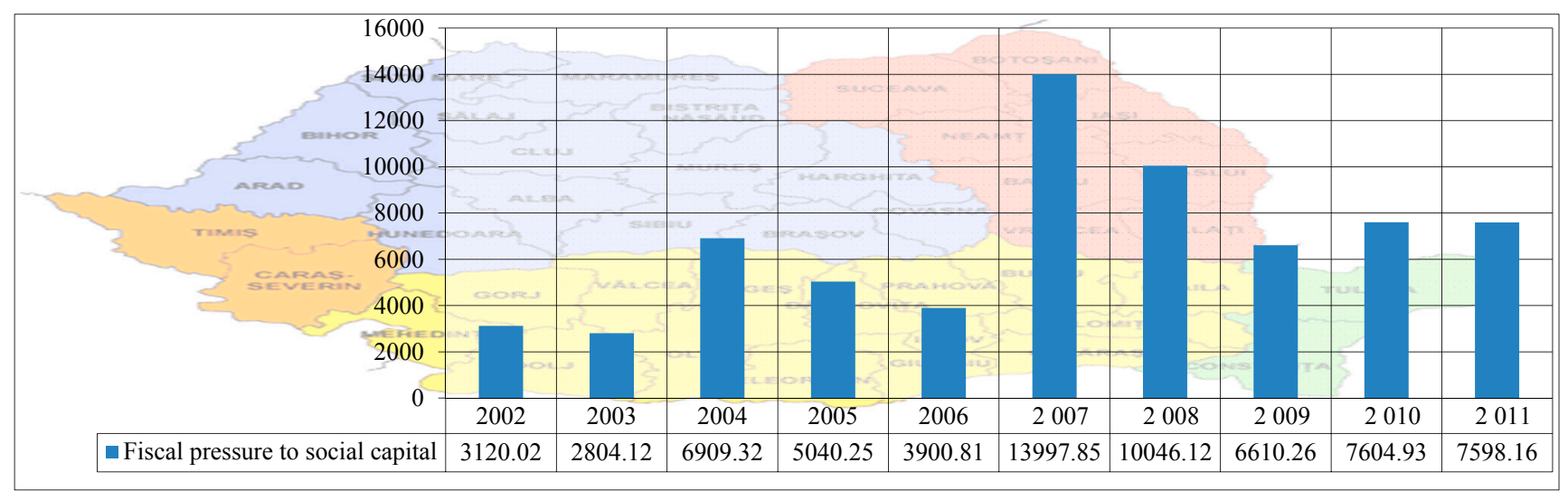

Source: Own calculus

Because share capital is very small for the companies in Romania, the fiscal pressure on it is very high and it has no economic significance.

\section{Fiscal Pressure to Expenses- RPFcht}

The indicator is calculated as a ratio of total taxes and social contributions and the total expenses of the company.

Figure 5. The evolution of fiscal pressure to expences

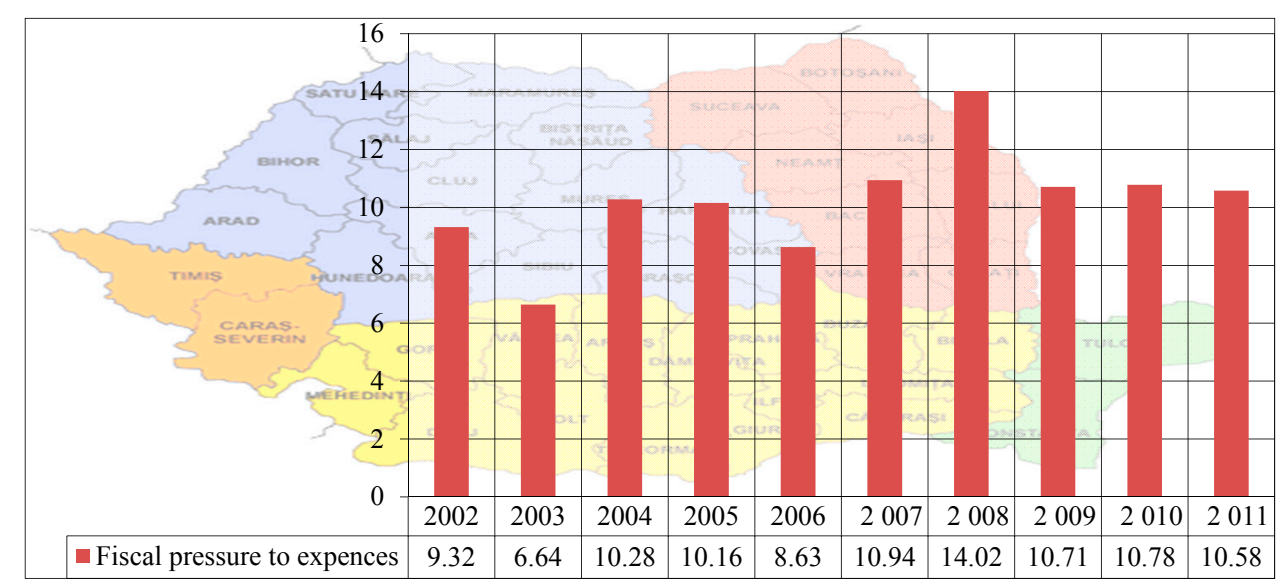


Source: Own calculus

In the total current expenditure the share of taxes and social contributions is at a normal level in economic terms, i.e. about $10 \%$.

Current liquidity (RLC)reflects the capacity of current assets available (stocks, unearned invoices, short-term investments, expenses in advance) to turn into cash on hand, meant to cover the outstanding debt of the economic entity.

It is estimated that the entity has a favourable liquidity if the current liquidity ratio is between $200 \%$ and $250 \%$.

From the chart below we can see that throughout the period under review the panel of companies had a liquidity which allowed it to meet due payments.

Figure 6 . The evolution of current liquidity ratio

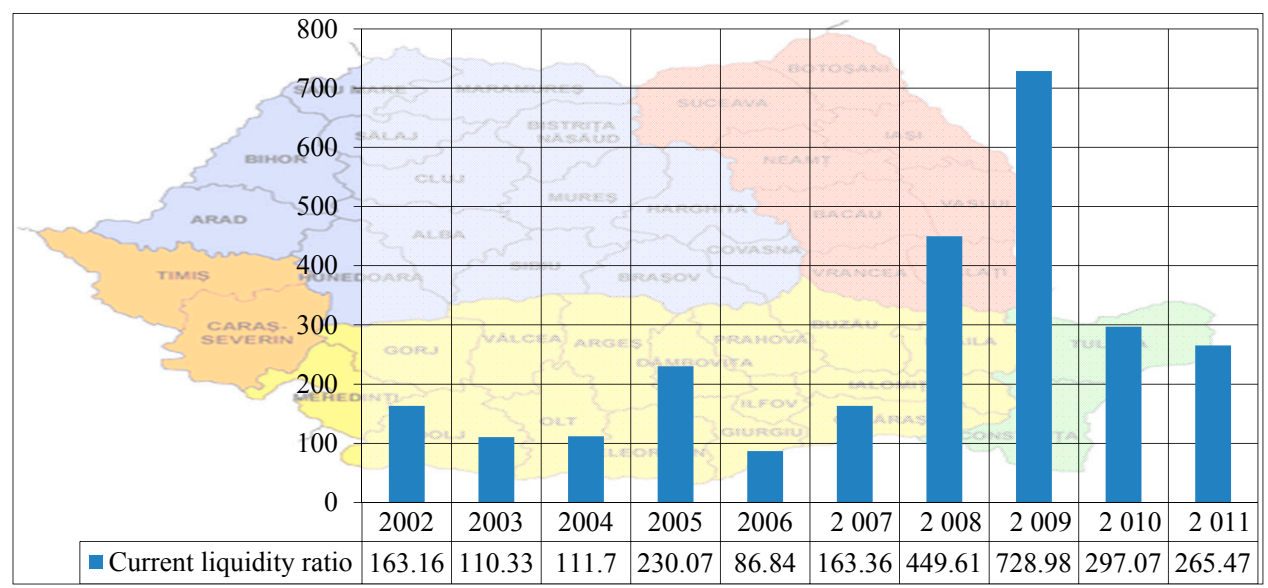

Source: Own calculus

Solvancy ratio (RSG)is determined as a percentage ratio between total assets and total liabilities of the company. 
Creditors are interested in a value as high as possible of the ratio, their guarantee being made up of the asset of the economic entity. The optimal level of the indicator is between $80 \%$ and $180 \%$, according to bank estimates.

Figure 7. The evolution of solvency ratio

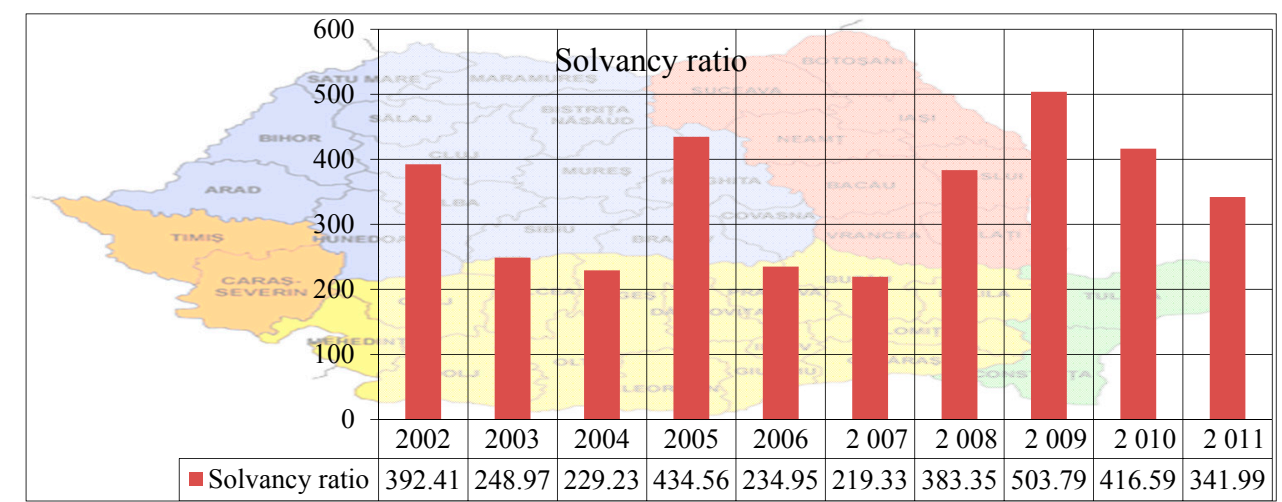

Source: Own calculus

The data in the chart above reveals a robust solvency which means a large long-term financial capacity of the enterprises.

Debt equity ratio (RIT) expresses the company's ability to cope with external payments and is calculated as a percentage ratio between debt and equity of the company. The optimum value of the indicator is in the green area, that is, between $0 \%$ and $30 \%$; between $31 \%$ and $50 \%$ we talk about the grey area; between $51 \%$ and $70 \%$ we stand in the red zone, and over $70 \%$ the company is in the red area.

Figure 8 . The evolution of debt to equity ratio 


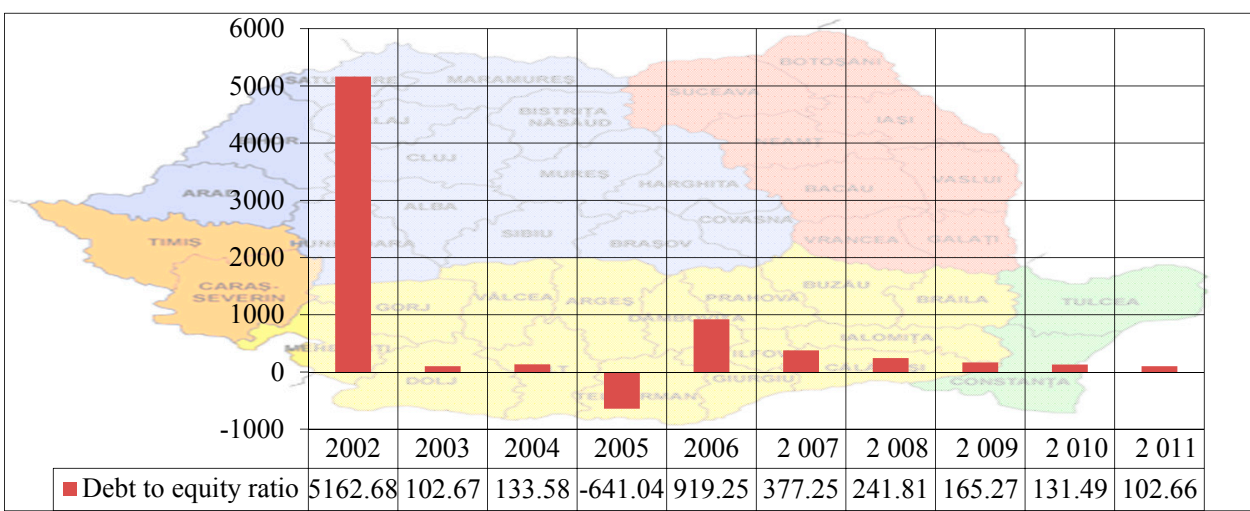

Source: Own calculus

Indebtedness of enterprises is very high and therefore it must be analysed in correlation with liquidity and solvency. This analysis indicates that enterprises in the panel cope with payments in both the short and long term.

Repayment capacity CR) highlights the resources available to the company to repay the loans and is calculated as a ratio of the self-financing capacity and the amount of due instalments. A higher value of the indicator means a greater capacity of the company to repay by due dates the instalments owed to banks.

Figure 9. The evolution of repayment capacity ratio

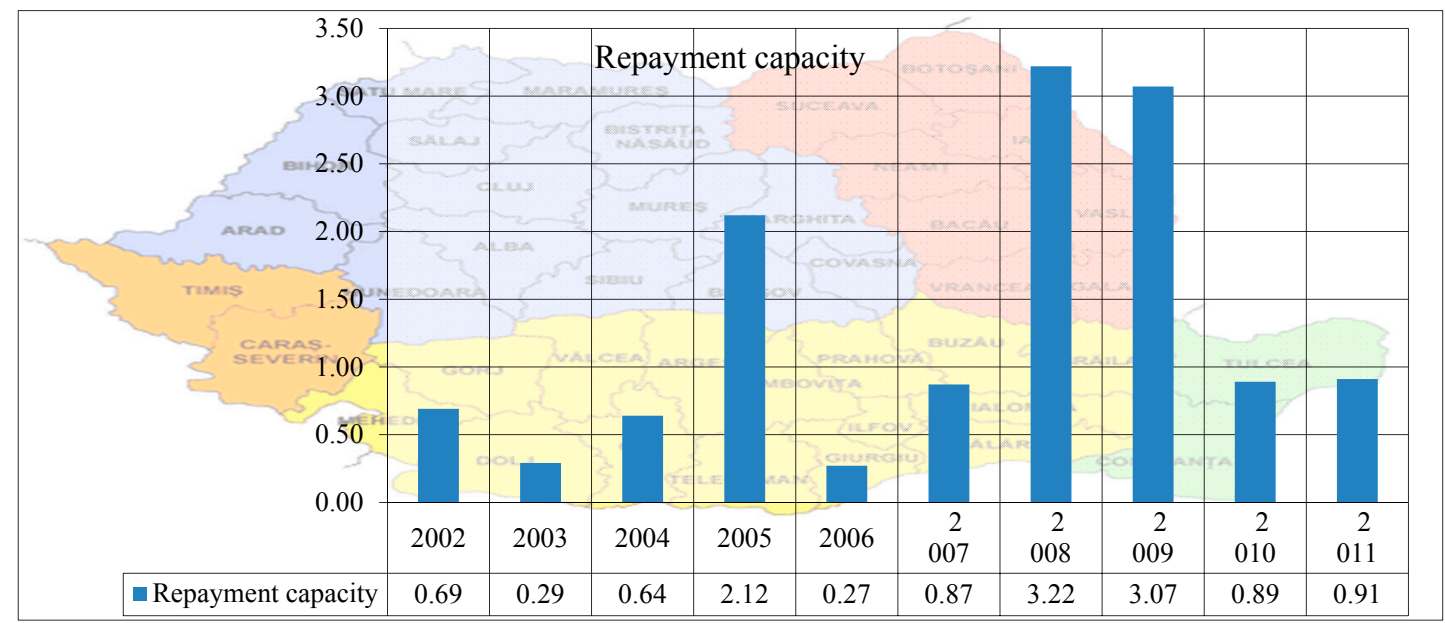

Source: Own calculus 
The data in the chart highlights generally an adequate capacity to pay bank instalments from their own resources.

Tangible self-financing rate (RAIC)is determined as the ratio between the self-financing capacity and the value of tangible assets. The indicator shows what percentage of own resources is allocated to investments.

Financing of investments from own resources, although not recommended by specialists, in times of financial crisis, may constitute a development model to overcome the crisis. It is noted that throughout the crisis period, investments were made from own resources.

Figure 10. The evolution of tangible self-financing rate

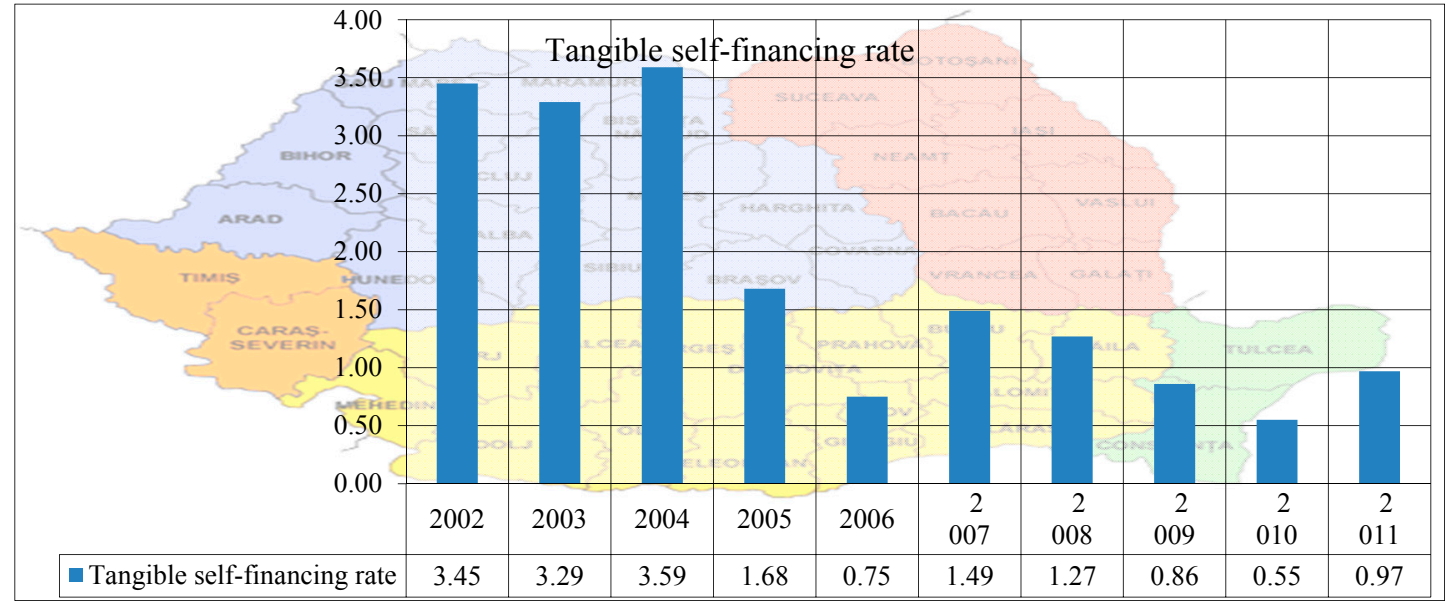

Source:Own calculus

a) Modelling the relationship between RLC - dependent variable andRPFva, RPFcpr, RPFca, RPFcs, RPFcht - independent variables: 


\begin{tabular}{|c|c|c|c|c|c|c|c|}
\hline Source & SS & df & \multicolumn{2}{|c|}{ MS } & & \multirow{2}{*}{$\begin{array}{l}\text { Number of obs } \\
\text { F( 5, } 44) \\
\text { Prob > }\end{array}$} & \multirow{2}{*}{$\begin{array}{rr}= & 50 \\
= & 5.11 \\
= & 0.0009\end{array}$} \\
\hline Model & 3323485.56 & 5 & 664 & 7.112 & & & \\
\hline Residual & 5728709.93 & 44 & 130 & 7.953 & & R-squared & $=0.3671$ \\
\hline Total & 9052195.48 & 49 & $184^{\prime}$ & 8.683 & & RoOt MSE & 360.83 \\
\hline rlc & Coef. & Std. & Err. & $t$ & $\mathrm{P}>|\mathrm{t}|$ & [95\& Conf. & Interval] \\
\hline rpfva & -4.579394 & 4.725 & 5121 & -0.97 & 0.338 & -14.10225 & 4. 943461 \\
\hline$r p f c p r$ & -.1397813 & -18 & 856 & -0.74 & 0.465 & -.5224108 & .2428483 \\
\hline ppfca & -4.435106 & 7.24 & 632 & -0.61 & 0.544 & -19.03772 & 10.16751 \\
\hline rpfes & .0014932 & .006 & 343 & 0.24 & 0.815 & -.0112728 & .0142593 \\
\hline $\operatorname{rpfcht}$ & 31.79305 & 6.91 & 078 & 4.60 & 0.000 & 17.85864 & 45.72746 \\
\hline _cons & 139.8524 & 200. & 893 & 0.70 & 0.489 & -264.2073 & 543.912 \\
\hline
\end{tabular}

From the table above it can be seen that although the overall model fits relatively well with corresponding data $\left(\mathrm{F}=5.11 ; \mathrm{p}<0.0009\right.$; adjusted $\left.\mathrm{R}^{2}=0.2952\right)$ is quite good because the regression coefficients corresponding to the variablesRPFva, PPFcaandRPFchtare significantly different from zero. Thus, the model becomes

$$
\mathrm{RLC}=139.8524-4.579394 \mathrm{RPFva}-4.435106 \mathrm{RPFca}+31.79305 * \mathrm{RPFcht}+\varepsilon,
$$

b) Modelling the relationship between RSG - dependent variable and RPFva, RPFcpr, RPFca, RPFcs, RPFcht - independent variables:

\begin{tabular}{|c|c|c|c|}
\hline Source & SS & $d f$ & MS \\
\hline Mode 1 & 4714817.87 & 5 & 942963.574 \\
\hline Residual & 12624108.4 & 44 & 286911.555 \\
\hline Total & 17338926.3 & 49 & 353855.638 \\
\hline
\end{tabular}

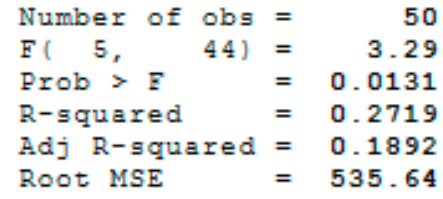

\begin{tabular}{r|rrrrrr}
\hline rsg & Coef. & Std. Err. & t & P>lt| & [958 Conf. Interval] \\
\hline rpfva & 4.281334 & 7.014309 & 0.61 & 0.545 & -9.855076 & 18.41774 \\
rpfepr & -.3896455 & -2818358 & -1.38 & 0.174 & -.9576483 & .1783573 \\
ppfca & -14.43973 & 10.75594 & -1.34 & 0.186 & -36.11689 & 7.237434 \\
rpfcs & -.0130588 & -0094032 & -1.39 & 0.172 & -.0320096 & .005892 \\
rpfeht & 35.73914 & 10.26375 & 3.48 & 0.001 & 15.0539 & 56.42437 \\
_cong & 307.8602 & 297.6207 & 1.03 & 0.307 & -291.955 & 907.6754 \\
\hline
\end{tabular}

From the table above it can be seen that although the overall model fits relatively well with corresponding data $\left(\mathrm{F}=3.29 ; \mathrm{p}<0.00131\right.$; adjusted $\left.\mathrm{R}^{2}=0.2719\right)$ is quite good because the 
regression coefficients corresponding to the variablesRPFva, PPFcaandRPFchtare significantly different from zero. Thus, the model becomes

$$
\mathrm{RSG}=307.8602+4.281334 \mathrm{RPFva}-14.43973 \mathrm{RPFca}+35.73914 * \mathrm{RPFcht}+\varepsilon,
$$

c) Modelling the relationship between RIT - dependent variable and RPFva, RPFcpr, RPFca, RPFcs, RPFcht - independent variables:

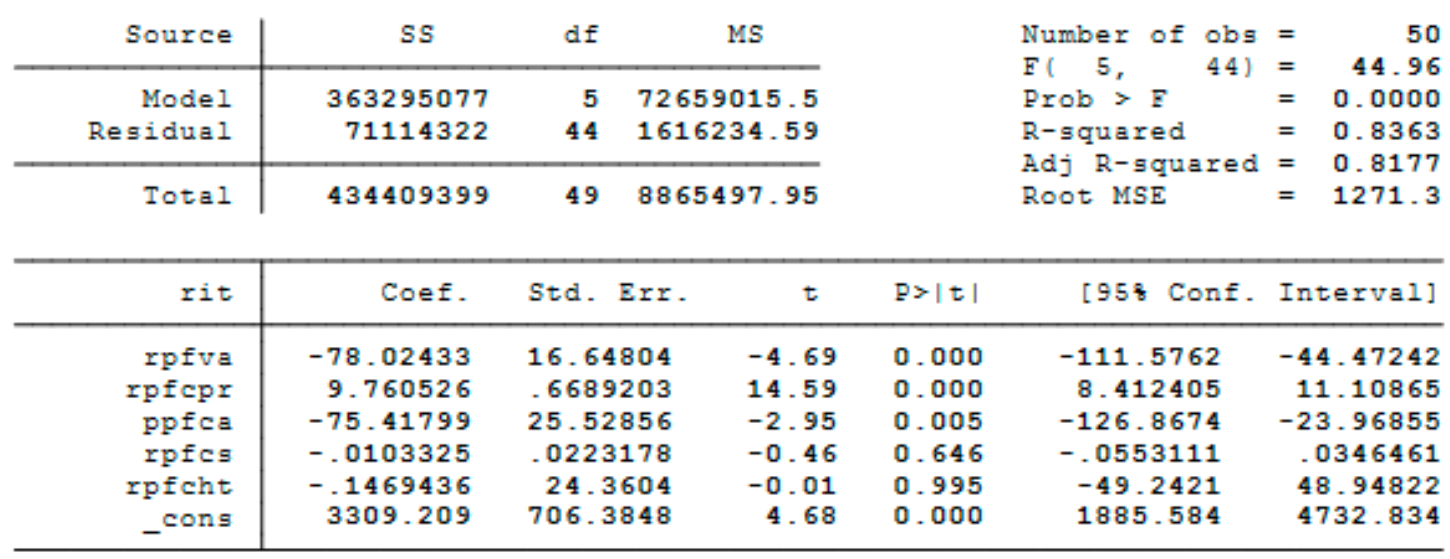

Unlike the first two sub-points, the model resulting from this set of processing is substantially better than the previous ones $\left(F=44.96 ; \mathrm{p}<0.0000\right.$; adjusted $\left.\mathrm{R}^{2}=0.8177\right)$, with total borrowing rate explained over $80 \%$ by the fiscal pressure indicators considered.

However, it should be mentioned that not all the explanatory variables considered are relevant, as for the variables RPFcs and RPFcht the corresponding regression coefficients are not significantly different from zero.

Thus, the final econometric equation for this relationship shall be:

$$
\mathrm{RIT}=3309.209-78.02433 * \mathrm{RPFva}+9.760526 * \mathrm{RPF} \mathrm{Ppr}-75.41799 * \mathrm{RPFca}+\varepsilon
$$


d) Modelling the relationship between CR - dependent variable and RPFva, RPFcpr, RPFca, RPFcs, RPFcht - independent variables:

\begin{tabular}{r|crc} 
Source & SS & df & MS \\
\hline Model & 120.111635 & 5 & 24.0223269 \\
Residual & 248.940226 & 44 & 5.65773242 \\
\hline Total & 369.051861 & 49 & 7.53167064
\end{tabular}

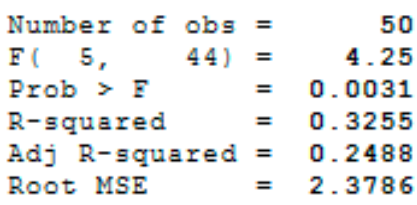

\begin{tabular}{r|rrrrrr}
\hline cr & Coef. & Std. Err. & $t$ & P $>$ t I & [958 Conf. Interva1] \\
\hline rpfva & -.0446774 & .0311481 & -1.43 & 0.159 & -.1074524 & .0180975 \\
rpfcpr & .0006251 & .0012515 & 0.50 & 0.620 & -.0018972 & .0031474 \\
ppfca & .1159553 & .0477634 & 2.43 & 0.019 & .0196945 & .2122162 \\
rpfcs & .0000332 & .0000418 & 0.79 & 0.431 & -.000051 & -0001173 \\
rpfcht & -.1248012 & .0455778 & -2.74 & 0.009 & -.2166572 & -.0329452 \\
cons & 2.297013 & 1.321631 & 1.74 & 0.089 & -.3665599 & 4.960586 \\
\hline
\end{tabular}

According to data from the table above, the present model manages to explain to an extent of about $25 \%$ the variance recorded by the CR over time within the considered panel. The explanatory variables that do not contribute with anything (statistically, regression coefficients equal to zero) in this model, namely RPFva, RPFcprandRPFcsshall therefore be removed

$\mathrm{CR}=2.297013+0.1159553 * \mathrm{RPFca}-0.1248012 * \mathrm{RPFcht}+\varepsilon$

e) Modelling the relationship between RAIC - dependent variable and RPFva, RPFcpr, RPFca, RPFcs, RPFcht - independent variables:

\begin{tabular}{r|crc} 
Source & SS & df & MS \\
\hline Model & 285.509369 & 5 & 57.1018739 \\
Residual & 273.470755 & 44 & 6.21524443 \\
\hline Total & 558.980124 & 49 & 11.4077576
\end{tabular}

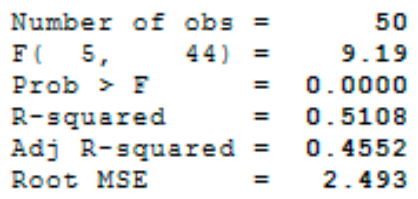

\begin{tabular}{r|rrrrrr}
\hline raic & Coef. & Std. Err & $t$ & P>|t| & [908 Conf. Interval] \\
\hline rpfva & .0585963 & .0326468 & 1.79 & 0.080 & .0037423 & .1134504 \\
rpfepr & .0078226 & .0013118 & 5.96 & 0.000 & .0056186 & .0100267 \\
ppfca & .0841429 & .0500614 & 1.68 & 0.100 & .0000282 & .1682576 \\
rpfcs & -.0000453 & .0000438 & -1.04 & 0.306 & -.0001189 & .0000282 \\
rpfeht & -.042954 & .0477707 & -0.90 & 0.373 & -.1232197 & .0373118 \\
_cons & -1.069442 & 1.385218 & -0.77 & 0.444 & -3.396927 & 1.258044 \\
\hline
\end{tabular}


The above table reveals that this model manages to explain to an extent of about $45 \%$ the variance recorded by the RAIC over time within the considered panel.

The explanatory variables that do not contribute with anything (statistically, regression coefficients equal to zero) in this model, namely RPFcs and RPFcht shall therefore be removed

$\mathrm{RAIC}=0.0585963 * \mathrm{RPFva}+0.0078226 * \mathrm{RPF} p \mathrm{p}+0.0841429 * \mathrm{RPF} a+\varepsilon$.

\section{Conclusions on the Impact of Taxation on the Enterprise}

The analysis undertaken above reveals that that taxes, fees and other duties, taxes and similar levies, respectively contributions to social security and social protection, influence the entity's financial position, by changes in the volume and structure of patrimonial assets and liabilities or by changes in the volume and structure of expenditure and profit/loss.

Obligations to the state budget are monetary liabilities, which at one time, being paid, influence in the sense of a decrease in monetary assets by reducing cash and cash equivalents, and may influence the economic entity's receivables.

In this sense we consider that value added tax is not an effective charge of the entity, but it can be: a debt by VAT to be paid, a receivable by VAT to be recovered, deferred debt by undue VAT in the credit balance, and a deferred debt by undue VAT in the debit balance, which influences the volume and structure of patrimonial assets and liabilities and implicitly the economic entity's financial position.

Expenditure with taxes, fees and other duties, taxes and similar levies, including contributions to social security and social protection represents drops in the profit/loss of the entity, increase in debts, respectively reductions in cash and cash equivalents. Expenditure with taxes and fees 
change the volume and structure of patrimonial assets and liabilities of the entity, respectively the volume and structure of results reflected in the balance sheet.

In conclusion, taxes and fees influence the three basic components of the balance sheet, namely assets, liabilities and equity and the financial equilibrium expressed through its relevant indicators: liquidity, solvency, repayment capacity and investment capacity.

\section{References}

1. Găban L. Financial crisis and its implications in risk and performance of banks in Romania, Analele Universității Târgu Jiu, Analele Universității Târgu Jiu, 2016, issue 2:146-152, ISSN: 2344-3685

2. Kuo, T. Chi, H., I-Hsuan, L., Sheng C., Do carbon taxes work? Analysis of government policies andenterprise strategies in equilibrium, Journal of Cleaner Production, 15 December $2016,139: 337-346$

3. Wu, C., Liang, W., Mai, C., Public Enterprise Privatization: A General Equilibrium Analysis, Review of Development Economics, May 2016, Vol. 20 Issue 2:456

4. Ji, J., Ye, Z., Zhang, S., Welfare analysis on optimal enterprise tax rate in China, Economic Modelling, July 2013, 33:149-158

5. Liang, Q., Hendrikse, G., Pooling and the yardstick effect of cooperatives, Agricultural Systems, March 2016, 143:97-105

6. Latorre, María C., Industry restructuring in transition after the arrival of multinationals: a general equilibrium analysis with firm-type costs differences, Post-Communist Economies. Dec2012, Vol. 24 Issue 4:441-463

7. Grenadier, S. R., Option Exercise Games: An Application to the EquilibriumInvestment Strategies of Firms, Review of Financial Studies, Summer 2002, Vol. 15 Issue 3: 691-721

8. Găban L. Cash flows in Romanian small and medium enterprises, Analele Universității Târgu Jiu,2016, issue 4: 46-52 
9. Latorre, María C., On the Differential Behaviour of National and Multinational Firms: A Within- and Across-sectors Approach, World Economy. Oct2013, Vol. 36 Issue 10, 12941317

10. Osborne, M. J., Pitchik, C., The nature of equilibrium in a location model, International Economic Review, Feb,1986, Vol. 27 Issue 1: 223-238

11. Coffinet, J., Pop, A., Monitoring Financial Distress in a High-Stress Financial World: The Role of Option Prices as Bank Risk Metrics, Journal of Financial Services Research, Dec.2013, Vol. 44 Issue 3:229-257

12. Isberg, S., Pitta, D., Using financial analysis to assess brand equity, Journal of Product \& Brand Management, 2013, Vol. 22 Issue 1:65-78

13. Žager, K., Sačer, I. M., Dečman, N., Financial ratios as an evaluation instrument of business quality in small and medium-sized enterprises International Journal of Management Cases. 2012, Vol. 14 Issue 4:373-385

14. Townsend, R., Financial Structure and Economic Welfare: Applied General Equilibrium Development Economics, Annual Review Economics, 2010 Sep; 2: 507-546

Acknowledgments. The authors gratefully acknowledge the staff of the entities for their help in collecting the data used in this paper. 